\title{
Proteomics of Bovine Myelin Sheath: Characterization of a Truncated Form of P0 by MALDI-TOF/TOF Mass Spectrometry
}

\author{
Antonio Qualtieri, Elena Urso, Maria Le Pera, \\ Massimo Scornaienchi, and Aldo Quattrone \\ Institute of Neurological Sciences, Mangone (CS), Italy
}

\author{
Leonardo Di Donna, Anna Napoli, and Giovanni Sindona \\ Department of Chemistry, University of Calabria, Arcavacata di Rende (CS), Italy
}

\begin{abstract}
The glycoprotein $\mathrm{P} 0$, the major structural protein of the peripheral nerve myelin, plays a critical role in holding myelin lamellae together via interaction of both extracellular and cytoplasmic domains. Mutations in the human P0 gene give rise to severe and progressive forms of dominantly inherited peripheral neuropathies like CMT1B. Here we report on the characterization of a bovine P0-derived protein of nearly $26 \mathrm{kD}$ that corresponds to the $\mathrm{P} 0$ protein truncated in its cytoplasmic domain. Matrix assisted laser desorption ionization (MALDI)-time-of-flight/time-of-flight (TOF/TOF) mass spectrometry (MS) analysis on its tryptic digest has provided a peptide mapping, the main difference of which from the normal P0 analog was represented by the absence of the cluster of peaks at $\mathrm{m} / \mathrm{z} 1513.7501,1530.7701$, and 1546.7651. The latter corresponds to the P0 fragment QTPVLYAMLDHSR and to its pyroglutamic and methionine-oxidized derivatives. The species at 1530.7701 covering the sequence 186-198 of $\mathrm{P} 0$ is not an artifact and might have a functional role in the myelin architecture. (J Am Soc Mass Spectrom 2006, 17, 117-123) (C) 2006 American Society for Mass Spectrometry
\end{abstract}

$\mathrm{P}$ 0 is a $30 \mathrm{kDa}$ glycoprotein of the peripheral nerve myelin involved in normal myelin organization and function [1]. The occurrence of some peripheral neuropathies, in mice, has been associated to absence or overexpression of $\mathrm{P0}$ [2]. In addition, mutations in the human P0 gene cause the inherited demyelinating peripheral neuropathy Charcot-Marie-Tooth disease type 1B (CMT1B) [3], the Dejerine-Sottas syndrome [4] (DSS), and congenital hypomyelination (CH) [5].

It has been recently shown that coexpression of wild type and cytoplasmically truncated P0 causes loss of wild-type function, presumably attributable to a dominant negative effect of the truncated molecule [6], and it has been demonstrated that the deletion of a 14 amino acid sequence in the cytoplasmic domain of P0 abolishes its adhesive function [7].

As a part of our ongoing project on the proteomics of the peripheral nerves [8-10], we have isolated by SDS-PAGE a low-molecular weight P0-related protein from bovine sciatic nerve. A previous report has already described the presence of a lower molecular

Published online January 10, 2006

Address reprint requests to Dr. G. Sindona, Department of Chemistry, University of Calabria, Via P. Bucci, cubo 12/C, I-87036 Arcavacata di Rende (CS), Italy. E-mail: sindona@unical.it weight P0-like protein in peripheral nerve myelin from rat. The latter, according to the authors, originated during the incubation at $37^{\circ} \mathrm{C}$ of nerve slice preparations and of crude myelin incubation by a cleavage caused by a not well defined protease that might be present in the myelin [11]. The mass spectrometry/mass spectrometry (MS/MS) approach exploited in the structure elucidation of the proteins separated by 1-D gel allows overcoming drawbacks that may arise from protein overlapping in the electrophoretic separation.

\section{Experimental \\ Protein Extract Preparation}

Bovine sciatic nerve, obtained from the local slaughterhouse within one hour of the animal's slaughter, was cut into pieces of nearly $1 \mathrm{~cm}$ long. These were snap frozen in liquid nitrogen and immediately transported to the laboratory and stored frozen at $-80{ }^{\circ} \mathrm{C}$ until use. A portion of the frozen nerve $(20-30 \mathrm{mg}$ wet) was thawed and washed in buffer $(0.32 \mathrm{M}$ Sucrose, $20 \mathrm{mM}$ Tris $\mathrm{pH}$ 7.5, $1 \mathrm{mM}$ EDTA, $1 \mu \mathrm{M}$ leupeptin, $1 \mu \mathrm{M}$ aprotinin, $0.2 \mathrm{mM}$ PMSF, $2 \mathrm{mM}$ 


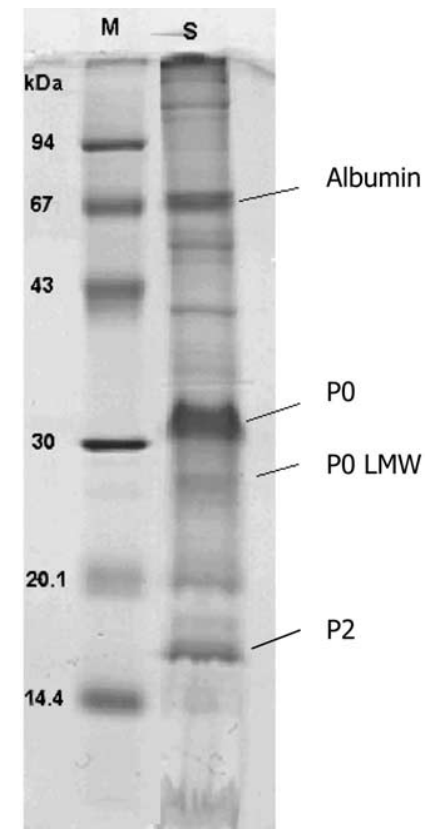

Figure 1. Homogeneous $15 \%$ SDS-PAGE separation of proteic extract from bovine sciatic nerve. In the gel, stained with Coomassie blue, the bands indicate the $\mathrm{P} 0, \mathrm{P} 0-\mathrm{LMW}$, and $\mathrm{P} 2$ proteins. $\mathrm{M}=$ molecular weight marker, $\mathrm{S}=$ sample.

sodium orthovanadate) at $4{ }^{\circ} \mathrm{C}$, rinsed with nondenaturing lysis buffer (10 mM Tris $\mathrm{pH}$ 7.4, $1 \mathrm{mM}$ EDTA, $1 \mu \mathrm{M}$ leupeptin, $1 \mu \mathrm{M}$ aprotinin, $0.2 \mathrm{mM}$ PMSF, $2 \mathrm{mM}$ sodium-orthovanadate), and directly sonicated by an Ikasonic U50 sonicator (Ikalabortechnik, Staufen, Germany) at the highest setting for 3 cycles of $20 \mathrm{~s}$, in $500 \mu \mathrm{l}$ of denaturing lysis buffer $(2.5 \%$ SDS, $62.5 \mathrm{mM}$ Tris- $\mathrm{HCl} \mathrm{pH} 6.8,1 \mathrm{mM}$ EDTA, $0.2 \mu \mathrm{M}$ PMSF, $10 \%$ glycerol, $1 \mu \mathrm{M}$ aprotinin, $1 \mu \mathrm{M}$ leupeptin). The homogenate was then centrifuged at 13,000 RPM for 10 min in a micro-centrifuge, and the supernatant was collected. The protein concentration in the extract was determined by a DC protein kit assay (Bio-Rad Laboratories, Hercules, CA) using BSA as a standard.

\section{Monodimensional SDS-Polyacrylamide Gel Electrophoresis (PAGE)}

Samples in lysis buffer were loaded onto gel without boiling and reducing agents (15 $\mu \mathrm{g}$ per lane). A minigel system of Laemmli [12] was utilized, consisting of a $15 \%$ homogeneous polyacrylamide resolving gel. The current was set at $25 \mathrm{~mA}$ and the migration was stopped when the tracking dye reached the down limit of the gel (nearly two h). The gel was than subjected to standard Coomassie blue staining.

\section{Protein In-Gel Digestion}

The Coomassie blue stained protein bands of interest were excised from the gel using a razor blade. A blank control was obtained using a piece of gel cut in

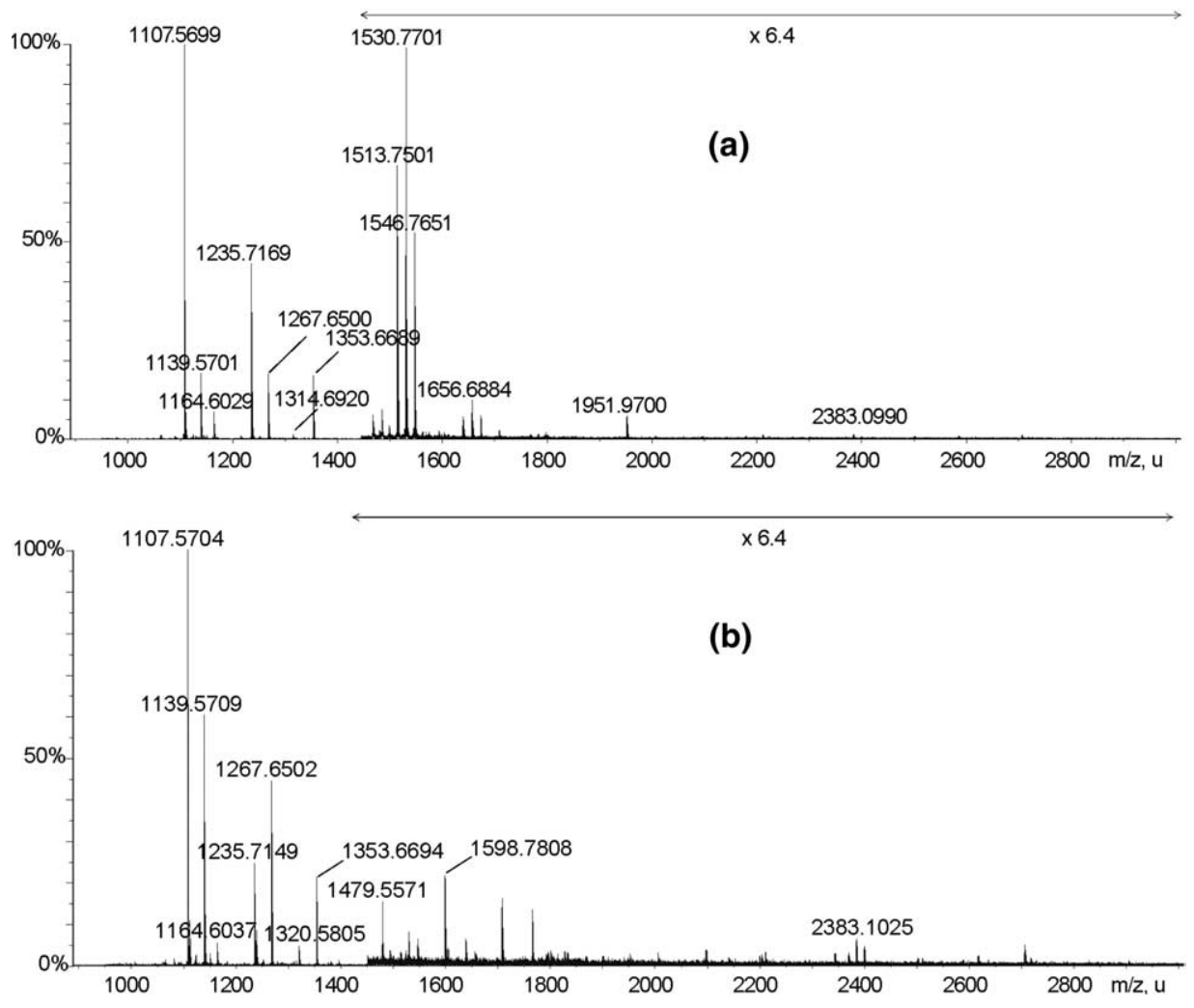

Figure 2. Peptide mass fingerprint of P0 (a) and P0-LMW (b) tryptic digest. The region above $1460 \mathrm{u}$ is expanded, in both spectra, by a factor of 6.4 to highlight the P0-LMW missing sequences. 
Table 1. MALDI-TOF peptide mapping of spectrum 2A and 2B, after recalibration

\begin{tabular}{|c|c|c|c|c|c|}
\hline Entry & Start-End & Observed & Miss & Accuracies (ppm) & Sequence \\
\hline \multicolumn{6}{|l|}{$P O$} \\
\hline 1 & $39-55$ & 1951.9700 & 1 & -1.74 & YOPEGGRDAISIFHYAK \\
\hline 2 & $46-55$ & 1164.6029 & 0 & 2.07 & DAISIFHYAK \\
\hline 3 & $56-67$ & 1353.6689 & 0 & 0.15 & GQPYIDEVGTFK \\
\hline 4 & 70-78 & 1107.5699 & 0 & 0.09 & IQWVGDPHR \\
\hline 5 & 70-79 & 1235.7169 & 1 & -42.08 & IOWVGDPHRK \\
\hline 6 & $80-101$ & 2383.0990 & 0 & -4.78 & DGSIVIHNLDYGDNGTFTCDVK \\
\hline 7 & $110-120$ & 1314.6920 & 0 & 1.90 & TSQVTLYVFEK \\
\hline 8 & $186-198$ & 1513.7501 & 0 & -1.85 & QTPVLYAMLDHSR Pyro-glu \\
\hline 9 & $186-198$ & 1530.7701 & 0 & 2.48 & QTPVLYAMLDHSR \\
\hline 10 & $186-198$ & 1546.7651 & 0 & 2.39 & OTPVLYAM(O)LDHSR \\
\hline \multicolumn{6}{|c|}{ PO LMW } \\
\hline $2^{\prime}$ & $46-55$ & 1164.6037 & 0 & 1.37 & DAISIFHYAK \\
\hline $3^{\prime}$ & $56-67$ & 1353.6694 & 0 & -0.22 & GQPYIDEVGTFK \\
\hline $4^{\prime}$ & $70-78$ & 1107.5704 & 0 & -0.36 & IOWVGDPHR \\
\hline $5^{\prime}$ & $70-79$ & 1235.7149 & 1 & -40.46 & IOWVGDPHRK \\
\hline $6^{\prime}$ & $80-101$ & 2383.1025 & 0 & -6.25 & DGSIVIHNLDYGDNGTFTCDVK \\
\hline
\end{tabular}

The mascot score and the sequence coverage were 98 and 39\% respectively, for P0.

a blank region of the gel and processed in parallel with the sample bands. The gel slices were subjected to reduction by $10 \mathrm{mM}$ DTT and alkylation by $55 \mathrm{mM}$ iodoacetamide before trypsin digestion [13, 14]. The gel slices were than washed with $50 \%$ acetonitrile/ 25 $\mathrm{mM} \mathrm{NH} \mathrm{CO}_{3}$, dried under vacuum, and rehydrated in $25 \mathrm{mM} \mathrm{NH} \mathrm{CO}_{3}$ containing trypsin (Promega, Madison, WI) $0.01 \mu \mathrm{g} / \mu \mathrm{l}$. The mixture was left standing overnight at $37^{\circ} \mathrm{C}$. Peptide were extracted by one change of water and two changes of $0.5 \%$ TFA $/ 50 \%$ acetonitrile at room-temperature and dried down.

\section{MALDI-TOF TOF MS/MS Peptide Sequence}

Mass spectra were recorded on a 4700 Proteomics analyzer with TOF/TOF optics (Applied Biosystems,
Foster City, CA). A 200-Hz frequency-tripled Nd:YAG laser was used.

An average of 5000 to 8000 laser shots were used to acquire the MS/MS spectra from $\alpha$-CHCA matrix. The collisions were carried out using air as collision gas and by setting the collision energy at $1 \mathrm{KV}$, defined as the difference between the accelerating potential, fixed at $8 \mathrm{kV}$ and the floating cell, kept at 7 $\mathrm{kV}$. The internal calibration was performed by using five peptides in the range 900-2500 $\mathrm{u}$ as standards.

MALDI spectra were elaborated by in-house software packages. MASCOT was used for database search. The search parameters used were peptide mass tolerance: 50 ppm; enzyme: trypsin (cuts C-term side of $K$ and $R$ unless next residue is $P$ ); variable modifications: Oxidation (M), Pyro-glu (N-term Q);

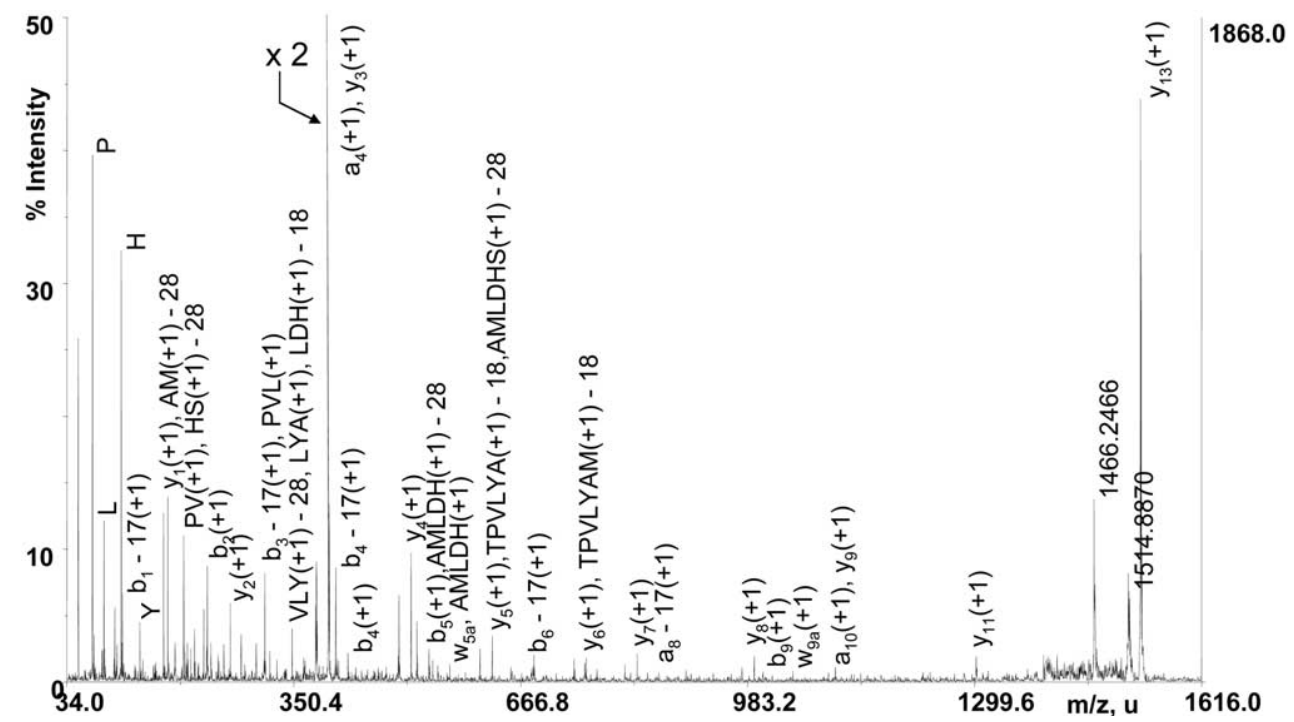

Figure 3. MALDI-TOF/TOF MS/MS spectrum of the tryptic peptide at $\mathrm{m} / \mathrm{z} 1530.77$ 


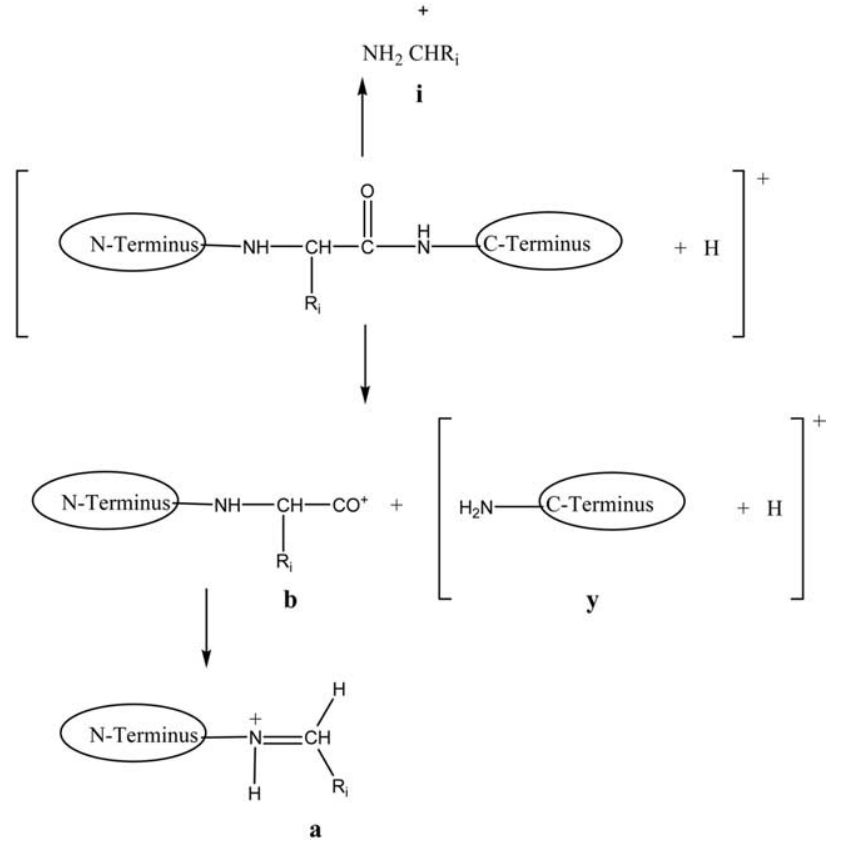

Scheme 1

protein mass: unrestricted; taxonomy: mammals; database: SwissProt 47.8. The detailed analysis of peptide mapping spectra was performed using DE NOVO sequence software.

\section{Results and Discussion}

The one-dimensional gel electrophoresis of the protein extract of bovine sciatic nerve displayed the known myelin proteins $\mathrm{P} 0$ and $\mathrm{P} 2$ as the most abundant bands (Figure 1). Even though the resolution of this chromatographic separation is not appropriate for an accurate investigation of the other less abundant nerve proteins, nevertheless a band migrating faster than that of the P0 one, of $\sim 26 \mathrm{kDa}$ molecular weight, was clearly detected in the Coomassie stained gel.

Mass spectrometry has been used extensively in neuroscience [15]. The tryptic digests of both P0 and P0-LMW were submitted to MALDI analysis in a MALDI-TOF/TOF instrument, and the spectra thus obtained are displayed in Figure 2a (P0) and 2B (P0LMW). The expanded region above $1460 \mathrm{u}$ highlights the missing sequences in the P0-LMW protein.

The main differences between the two spectra are attributable to the absence of the clusters centered around $m / z 1530$ in the spectrum of Figure 2b. Moreover, the matching of ions sets present in both Figure 2a and $b$ with the MASCOT database leads to the identification of both proteins as the well-known P0, with a similar score. It can be assumed, therefore, that $\mathrm{P} 0$ and P0-LMW proteins are structurally similar. The mass fingerprint of the spectrum reported in Figure 2a, used to identify the protein, leads to the recognition of several sequence-specific peptides (Table 1).

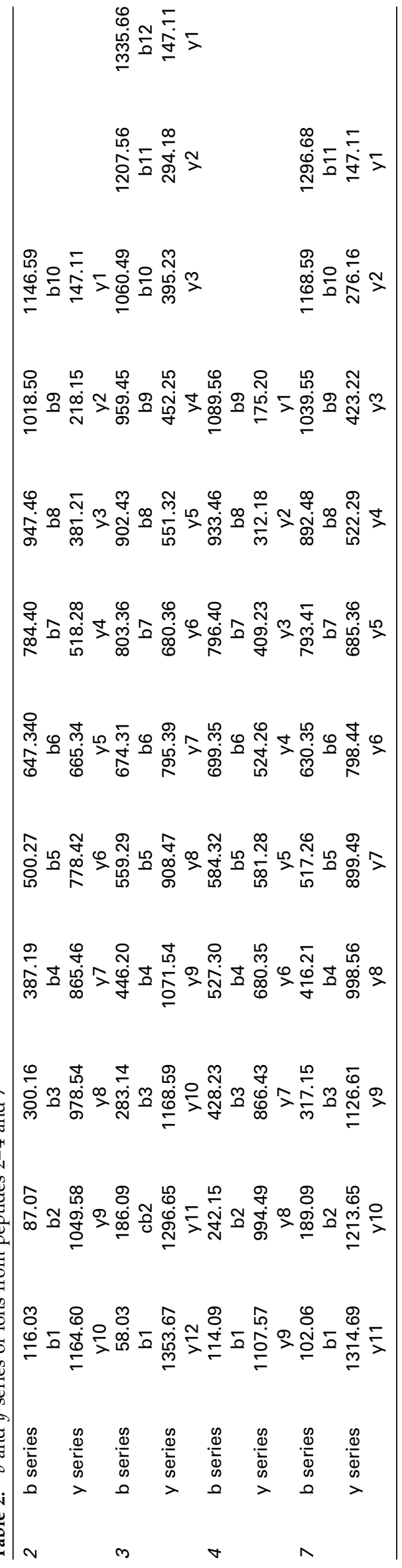



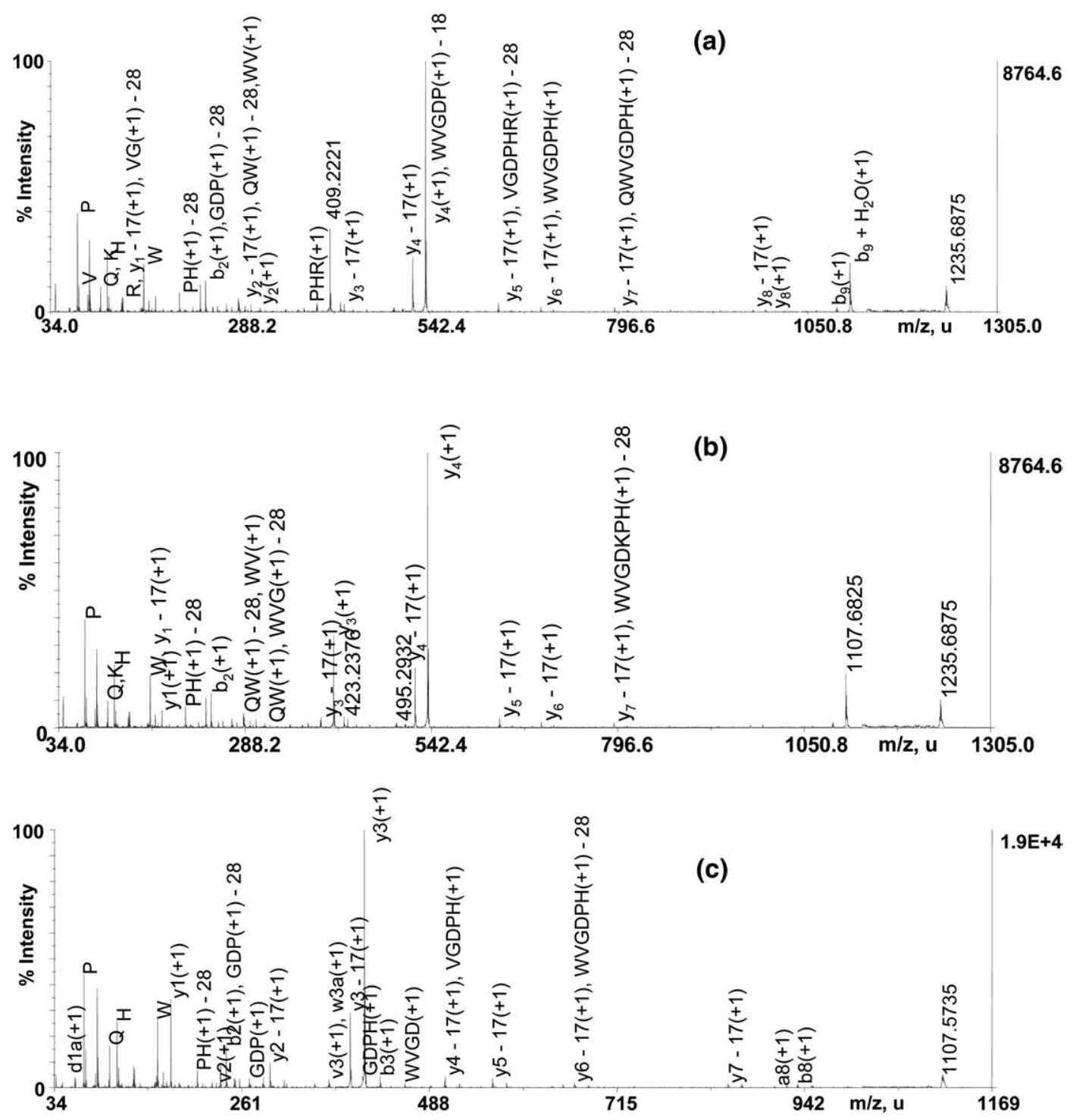

Figure 4. MALDI-TOF/TOF MS/MS spectrum of the tryptic peptide at $m / z$ 1235.68: Matching of (a) IQWVGDPHRK and (b) IQWVGDKPHR sequences by DATA EXPLORER Software. (c) MALDI-TOF/ TOF MS/MS spectrum of the tryptic peptide at $\mathrm{m} / \mathrm{z}$ 1107.57: Matching of IQWVGDPHR by DATA EXPLORER Software.

The protonated species of the modified peptides 8 $(\mathrm{m} / \mathrm{z}$ 1513.7501), $9(\mathrm{~m} / \mathrm{z} 1530.7701)$, and $10(\mathrm{~m} / \mathrm{z}$ 1546.7651), respectively (Table 1 and Figure 2a), are those missing in the spectrum of peptide P0-LMW (Figure 2b). They are recognized as the peptide QTPVLYAMLDHSR, at $\mathrm{m} / \mathrm{z} 1530.7701$, its oxidized form, at $\mathrm{m} / \mathrm{z} 1546.7651[-\mathrm{M}(\mathrm{O})-]$, and the dehydrated species at the glutamic moiety at $\mathrm{m} / \mathrm{z} 1513.7501$ [pyroGlu-].

The two satellites peptides attributable to classic chemistry that the wild type sequence has gone through during sample preparation provide additional clues on the structure of the 186-198 segment of the P0 protein sequence, the identification of which was based on the information input regarding the molecular weight and of the selected enzymatic procedure only.

An independent validation of a peptide primary structure is now offered by the TOF-TOF methodology that allows the use of the classic ion chemistry principles to establish the structure of unknowns [16].

Table 3. De novo sequences corresponding to the peptide at $\mathrm{m} / \mathrm{z}$ 1235

\begin{tabular}{lccr}
\hline & & \multicolumn{2}{c}{ Mass Accuracy } \\
\cline { 3 - 4 } \multicolumn{1}{c}{ Sequences } & Calculated & (1) & \multicolumn{1}{c}{$(2)$} \\
\hline \hline 1 IOWVGDKPHR & 1235.6649 & -42.10 & 0.48 \\
2 IQADVGDKPHR & 1235.6496 & -54.49 & 11.90 \\
3 IKAD $\underline{\text { VGDKPHR }}$ & 1235.6860 & -25.02 & -17.57 \\
4 IKW $\underline{\underline{V} \text { GDKPHR }}$ & 1235.7013 & -12.63 & -29.96 \\
\hline
\end{tabular}

(1) Initially observed mass $\mathrm{m} / \mathrm{z}$ 1235.7169; (2) Observed average mass $\mathrm{m} / \mathrm{z}$ 1235.6643 , after three independent calibration in the $\mathrm{m} / \mathrm{z}$ range $1107 \div 1353$. 
In particular, an indirect proof of the presence of Leucine (L) or Isoleucine (I) at the 5 and 9 positions of the primary structure of the examined peptide (Table 1 , entry 9) would be important [17].

When the protonated peptide at $\mathrm{m} / \mathrm{z} 1530.7701$ is selected by the first TOF and allowed to react in the floating cell with inert gas (see the Experimental section), the MS/MS spectrum reported in Figure 3 was obtained after ion analysis performed by the second TOF operated in the reflectron mode. The MS/MS spectrum provided the complete sequence of the peptide by the appearance of the appropriate $y, b$, and $i$ ions (Scheme 1). Moreover, the presence of $L$ residues was confirmed by the presence of the $\mathrm{w}_{\mathrm{i}}$ ions at $\mathrm{m} / \mathrm{z} 1046.47$ and 568.25.

The QTPVLYAMLDHSR corresponding to the 186198 sequence of the bovine P0 myelin was, therefore, confirmed. Similarly, it was confirmed for the structure of the modified peptides 8 and 10 (Table 1).

The MS/MS experiments were also carried out on the other relevant tryptic peptides $2-4$ and 7 (Table 2), the structures of which were easily confirmed by the appearance of the full $y$ and $b$ ion series.

A deeper evaluation of the available data were needed to validate sequence 5 (Table 1). Database search of the spectrum in Figure $2 \mathrm{a}$ identifies this species, initially observed at $\mathrm{m} / \mathrm{z} 1235.7169$, as the segment $70-79$ of P0 myelin with very low mass accuracy, $-42.10 \mathrm{ppm}$. Its MS/MS spectrum (Figure 4a) was sufficiently informative; however, a relevant fragment at $m / z 409.22$ was not recognized.

The de novo-sequencing analysis, starting from $\mathrm{m} / \mathrm{z}$ 392 , provided four other sequences (Table 3), having in common the last eight amino acid sequences that might fit the experimental data.

The discriminating parameter among the sequences 1-4 (Table 3 ) is represented by the mass accuracy only (Table 3, third column) that is related to the calibration initially used in the acquisition of spectrum 2A. The instrument was then recalibrated three times in the interval $1107 \div 1353$, using the peptides 3 and 4 (Table 1) as internal standards, obtaining an average value of $1235.6643 \mathrm{u}$ and the mass accuracies reported in the fourth column of Table 3. Peptides 5 (Table 1) and $\mathbf{1}$ (Table 3) are isobaric, therefore, on the ground of the recalculated mass accuracy of $0.48 \mathrm{ppm}$ only, both of them might correspond to the 70-79 segment of $\mathrm{P} 0$.

As previously mentioned, the identification of 5 from mass peptide fingerprint left one mass fragment unassigned, whereas the de novo-sequencing analysis of $\mathbf{1}$ was not able to recognize the species at $m / z$ 1107.68, if the species were considered to be the 70-79 fragment of P0 (Figure $4 b$ ).

This is a particular case in which the databases or the fragmentation software cannot unambiguously recognize the structure of a peptide. It can be suggested, however, that the ionic species at $\mathrm{m} / \mathrm{z} 409.92$ could be due to a consecutive reaction path taken by the ion fragment at $m / z$ 1107.68. Evidence is provided by the observation that the MS/MS spectrum of 1107.57 (entry 4, Table 1) gives rise to the fragment at $\mathrm{m} / \mathrm{z} 409.22$, which is in turn recognized either by the database or by the in silico fragmentation tool as a typical ion of that sequence (Figure 4c).

It can be assumed, therefore, that the electrophoretic spot submitted to tryptic digestion corresponds to the well known P0 protein. Accordingly, the new P0-LMW myelin protein is of necessity strictly related to it. The QTPVLYAMLDHSR sequence is, therefore, unambiguously missed in the P0-LMW, and represents a good marker of the P0 cytoplasmic domain region. The presence of this truncated protein in samples obtained from fresh frozen nerve extracts and rigorously processed at low temperatures let us to exclude the possible involvement of an endogenous protease during the experimental manipulations, as suggested by Agrawal and coworkers [11]. It can be assumed, therefore, that this P0 derived protein is not an artifact but that it is usually present in the myelin membrane and that it might have a functional role in the myelin architecture.

\section{Conclusions}

We have been able to identify by SDS-PAGE and mass spectrometry a $\mathrm{P} 0$-like protein in the pool of myelin sheath proteins characterized by a molecular weight lower than that of P0 and lacking almost one peptide sequence among those already described in previous experiments [8-10].

The specificity of tandem mass spectrometry, now available with MALDI ionization, provides the advantage of validating the peptide structure by means of classic gas-phase ion-chemistry tools applied to peptide enzymatic digest, thus offering an unique method to validate the database searching against mismatch that could arise from the fact that, in this case too, the peptide sequence is theoretically reconstructed from cDNA.

\section{Acknowledgments}

The authors acknowledge funds from the University of Calabria and from MIUR PON avviso 68.

\section{References}

1. Quarles, R. H. Myelin sheaths: Glycoproteins involved in their formation, maintenance, and degeneration. Cell. Mol. Life Sci. 2002, 59, 1851-1871.

2. Wrabetz, L.; Feltri, M. L.; Quattrini, A.; Imperiale, D.; Previtali, S.; D'Antonio, M.; Martini, R.; Yin, X.; Trapp, B. D.; Zhou, L.; Chiu, S. Y.; Messing, A. P-0 glycoprotein overexpression causes congenital hypomyelination of peripheral nerves. J. Cell. Biol. 2000, 148, 1021-1033.

3. Berger, P.; Young, P.; Suter, U. Molecular cell biology of Charcot-MarieTooth disease. Neurogenetics 2002, 4, 1-15.

4. Warner, L. E.; Hilz, M. J.; Appel, S. H.; Killian, J. M.; Kolodny, E. H.; Karpati, G.; Carpenter, S.; Watters, G. V.; Wheeler, C.; Witt, D.; Bodell, A.; Nelis, E.; VanBroeckhoven, C.; Lupski, J. R. Clinical phenotypes of different MPZ (P-0) mutations may include Charcot-Marie-Tooth type 1B, Dejerine-Sottas, and congenital hypomyelination. Neuron 1996, 17, 451-460.

5. Giese, K. P.; Martini, R.; Lemke, G.; Soriano, P.; Schachner, M. Mouse $\mathrm{p}(0)$ gene disruption leads to hypomyelination, abnormal expression of 
recognition molecules, and degeneration of myelin and axons. Cell 1992, $71,565-576$

6. Ekici, A. B.; Oezbey, S.; Fuchs, C.; Nelis, E.; Van Broeckhoven, C.; Schachner, M.; Rautenstrauss, B. Tracing Myelin Protein Zero (P0) in vivo by construction of P0-GFP fusion proteins. BMC Cell. Biol. 2002, 3, 29-37.

7. Xu, W. B.; Shy, M.; Kamholz, J.; Elferink, L.; Xu, G.; Lilien, J.; Balsamo, J. Mutations in the cytoplasmic domain of P0 reveal a role for PKCmediated phosphorylation in adhesion and myelination. J. Cell. Biol. 2001, 155, 439-445.

8. Le Pera, M.; Urso, E.; Scornaienchi, M. C.; Qualtieri, A. Two dimensional electrophoresis of bovine peripheral nerve: Preliminary data. Proceedings of the 1st IHUPO National Congress; Napoli, Italy, September, 2003.

9. Sindona, G.; Di Donna, L.; Napoli, A. Identification of the cleavage site of bovin myelin sheat protein 0 by MALDI-MS/MS. Proceedings of the 1st IHUPO National Congress; Napoli, Italy, September, 2003.

10. Qualtieri, A.; Le Pera, M.; Urso, E.; Crescibene, L.; Valentino, P.; Bastone, L.; Bagala, A.; Bono. F.; Nistico, R.; Scornaienchi, M. C.; Quattrone, A. A proteomic approach to the study of the peripheral neuropathies: Preliminary results. Proceedings of the XXXV Congresso SIN; Genova, Italy, September 2004. Neurological Sciences 25 (Suppl.), 2004, S66.

11. Agrawal, H. C.; Agrawal, D.; Strauss, A. W. Cleavage of the P0 glycoprotein of the rat peripheral nerve myelin: tentative identification of cleavage site and evidence for the precursor-product relationship. Neurochem. Res. 1990, 15, 993-1001.

12. Laemmli, U. K. Cleavage of structural proteins during the assembly of the head of bacteriophage T4. Nature 1970, 227, 680-685.

13. Hellman, U.; Wernstedt, C.; Gonez, J.; Heldin, C. H. Improvement of an in-gel digestion procedure for the micropreparation of internal protein fragments for amino-acid sequencing. Anal. Biochem. 1995, 224, 451-455.

14. Jeno, P.; Mini, T.; Moes, S.; Hintermann, E.; Horst. M. Internal sequences from proteins digested in polyacrylamide gels. Anal. Biochem. 1995, 224, 75-82.

15. Paulson, L.; Persson, R.; Karlsson, G.; Silberring, J.; BierczynskaKrzysik, A.; Ekman, R.; Westman-Brinkmalm, A. Proteomics and peptidomics in neuroscience. Experience of capabilities and limitations in a neurochemical laboratory. J. Mass Spectrom. 2005, 40, 202-213.

16. Aiello, I.; Di Donna, L.; Ghedini, M.; La Deda, M.; Napoli, A.; Sindona, G. Charge-transfer matrixes as a tool to desorb intact labile molecules by matrix-assisted laser desorption/ionization. Use of 2,7-dimethoxynaphthalene in the ionization of polymetallic porphyrins. Anal. Chem. 2004, 76, 5985-5989.

17. Runker, A. E.; Kobsar, I.; Fink, T.; Loers, G.; Tilling, T.; Putthoff, P.; Wessig, C.; Martini, R.; Schachner, M. Pathology of a mouse mutation in peripheral myelin protein $\mathrm{P0}$ is characteristic of a severe and early onset form of human Charcot-Marie-Tooth type 1B disorder. J. Cell. Biol. 2004, 165, 565-573. 